\title{
Sansibar oder der wirkliche Grund
}

Drama in a College German Language Class

\author{
Ulrike Brisson
}

\begin{abstract}
The subject of the investigation is a drama-in-education approach to improve students' access to German language, literature, and culture. It is based on an action research project carried out at a fourth-year German language class at a US university. This essay constitutes a critical exploration of the drama activities as suggested in Manfred Schewe's and Heinz Wilms' book Sansibar. Texte lesen und inszenieren (1995). From the results of the project, the paper addresses questions regarding projectoriented or process-oriented drama, it offers hints and caveats for teachers using drama activities for the first time, and proposes activities that go beyond the suggestions by Schewe and Wilms.
\end{abstract}

\section{Introduction: Why Drama-in-Education in the $21^{\text {st }}$ Century}

Drama in foreign language instruction was a "first" for both teacher and students in a particular teaching sequence taught to fourth-year students of German at college level in the U.S., and the experiences and results of this action research project form the basis of this article. The goal of this article is to raise questions about teaching literature in foreign language classes in general and to discuss the benefits and challenges of using a drama-in-education approach for teaching literature. The results of this research are directed especially to those foreign language educators who, as it was in my case, are new to drama in education in order to help them learn what works and does not work so well. Furthermore, understanding of drama projects can be deepened by reporting on various attempts and how they were put into practice, which this essays intends to do.

My motivation for using drama-in-education techniques to teach literary works is based on my own (frustrating) experiences in literature classes as a student and (disappointing) observations of such courses as a teacher. All too often I have found these classes being taught in an entirely teacher-centered way. What was named a discussion was in fact a ping-pong situation or in Alexander's words a " "recitation script" created by the teacher asking questions 
and some of the students trying to come up with the answer they hoped would match that of their teacher. ${ }^{1}$ In larger classes, only a few were actively involved while others listened passively or were pre-occupied with activities, such as reading cartoons or drawing pictures. What was meant to excite all students, ended up stimulating only a few, and their teachers complained that many were not "getting it."

In general, literature is given much cultural importance in the teaching both of the native as well as of foreign languages. Yet it seems to fail in reaching and educating the majority of the population, especially in today's fast-pace, hard-pressed society. According to Bowker, a leading bibliographic information provider, "U.S. book production plummets 18,000 in 2005 " 2 and according to a literacy survey " 42 million adults in the US are 'functionally illiterate,' meaning that they can't read the front page of the newspaper."3 Other statistics of fourth graders do not show significant changes in literacy levels from 1991-2001 of this age group. ${ }^{4}$ What they do not tell is how the children's reading habits will develop into their adult lives. Differences exist, of course, in social class, ethnicity, gender, and country of residence. The overall trend to spending less time with longer texts is, however, apparent. This is especially true at a time in which learners are primarily visually oriented, no longer learn in a linear but in a simultaneous and multiple manner, and appear to be living in a world very different from that of the characters of the canonical works they have been reading in class. Not only have learning habits changed but general life-styles as well. Today's students are occupied with many more sedentary activities than half a century ago and their experiential world is largely second-hand rather than hands-on. Based on similar observations Schewe postulates:

[H] eute Studierende, deren Sozialisation stark von den neuen (Internet-) Medien geprägt wurden, nehmen anders wahr als frühere Generationen. Literaturvermittler müssen dieser Tatsache stärker ins Auge blicken und Formen des Umgangs mit Literatur entwickeln, die neu ansprechen (2002: 34). ${ }^{5}$

1 In Alexander's view talk is necessary for "human development and learning." In the classroom, talk should neither be dominated by "closed teacher questions" nor by "pseudo-questions" that provide too little guidance and not enough challenges. Instead, learner-teacher talk should be based on "interactive opportunities" or "dialogic talk," which takes into account the students' discourse level while providing challenging subject matter and avoiding preconceived answers. Robin Alexander 2005, Culture Dialogue and Learning: Notes on an Emerging Pedagogy, Nov. 30, 2006, <http://www.robinalexander.org.uk/docs/IACEP_paper_050612.pdf> 2-3, 16-18.

2 Bowker, Publishing Central, Oct. 17, $2006<$ http://www.publishingcentral.com/ articles/20060516-23-2748.html>.

${ }^{3}$ Educational Cyber Playground, Oct. 17, 2006, <http://www.edu-cyberpg.com/Literacy/ what.asp>.

${ }^{4}$ U.S. Department of Education, "International Comparisons in Fourth-Grade Reading Literacy: Findings from the Progress in International Reading Literacy Study (PIRLS)" 2001, 17 10-2006, <http://nces.ed.gov/pubs2003/2003073.pdf>.

5 "Today's students whose socialization has been strongly influenced by the new (internet) media perceive the world differently than earlier generations. Teachers of literature need to take this fact into account more acutely and should develop new and more appealing forms of 
New approaches are therefore imperative, and drama in education offers one such possibility.

To provide my students with a counter-weight to their virtual but sensoriallydeprived world, I found teaching with drama-in-education activities an effective means to involve more students in the classroom and to stimulate their own imaginary world. It further allowed me to bring to life the figures in the narratives, because the learners reached a much higher degree of identification in a true acting situation than in a purely analytical approach. In the way literature has traditionally been taught, it often seems too abstract to the students and lacks so-called "Betroffenheit" (being emotionally moved), which in turn makes learners shy away from reading literature. If one of the goals of teaching literature in both the native and foreign language classroom is cultural literacy then, I would say, it can be taught more effectively through drama than traditional methods because differences are not only talked about but actually "lived" and negotiated. ${ }^{6}$

A number of questions have arisen from my experiences and observations of literature classes in a foreign language setting. These questions have to do with language, content, aesthetic value, and the students' learning outcome:

- How does literature help students enlarge their passive and active vocabulary?

- How does it improve their structuring skills or ability to write a well-structured essay?

- How can the instructor create an interface between the imaginary text and the students' worlds?

- How can students be guided from a literal to a more symbolic reading (How does one make them "get it")?

- How can the instructor sensitize students to the aesthetic value (beauty of language and style) of literary works?

- How can instructors effectively expose students to a symbolic world outside their own in order to increase their knowledge about the scope of human existence?

- How can educators foster cultural sensitivity and intercultural competence through literary texts?

- How can the students' overall performance skills (Handlungskompetenz) be improved through the reading, understanding, and interpreting of literature?

dealing with literature." Trans. U.B.All the translations, unless otherwise indicated, are mine (U.B.).

${ }^{6}$ I use "lived" in quotation marks here because the scenario of a specific situation is more real than reading and talking about it, but still a step removed from a real-life experience. 
These were some of the questions that motivated me to look for alternative ways of engaging students in the literature taught in a foreign language, in this case German.

Schewe/Scott (2003: 58) also argue for greater accountability of teachers of literature, for them "to become pro-active and lay open what exactly is happening in their lecture theatres and seminar rooms". Even (2003: 143) promotes drama techniques for teaching grammar in foreign languages that go beyond "die kognitive Durchdringung der Fremdsprache" [the cognitive comprehension of the foreign language]. A drama approach to grammar not only strengthens the learners' language competence, but also means "die Lernenden zur Darstellung ihres ganzen Selbst mit und in der Fremdsprache zu befähigen" [to enable students to a present their entire self with and in the foreign language]. In addition, as teaching contexts always vary and transferring ideas from one context to another is not easy, drama projects can function as a bridge. Using drama-in-education techniques thus seemed for me a promising and pro-active alternative to the traditional approaches and an opportunity to reach students of the twenty-first century.

The hypothesis of this article is that teaching literature through dramain-education techniques can bring the students back from the virtual into the real world, reconnect them with themselves as a whole, strengthen their interpersonal, and cultural skills, as well as stimulate their motivation to learn beyond the classroom. A number of these goals are difficult to measure, especially alterations of behavior outside and beyond the classroom. Nevertheless, changes of motivation levels are observable in the classroom and some of the responses are listed at a later point.

As every foreign language educator knows, there is no teaching method that provides answers to all questions related to foreign language instruction, nor does drama in education make this claim. This essay rather offers a critical assessment of drama in the foreign language classroom based on a study in a senior-level university German class with a focus on speaking and writing. Before presenting this action project, I would first like to concentrate on what is actually meant by the term "drama in education."

\section{Drama in Education - Definitions}

The idea of drama in education encompasses a variety of concepts: educational drama or drama in education (Heathcote 1998; Bolton 1984), creative drama (McCaslin 1996), drama techniques and dramatic activities (Pitman 1997), social dramatic play (Wagner 1998), drama activities (Dougill 1987), and process drama, which according to Kao/ O'Neill, arose in the 1990s in the US and Australia. The term "process drama" is almost identical to the term "drama in education" as used by Heathcote/Bolton (quoted in Kao/O'Neill 1998: ix). A general definition of educational drama, in Heathcote's words, "is 'role-taking', either to understand a social situation more thoroughly or to experience imaginatively via identification in social situations" (quoted in 
Kao/O'Neill 1998: 49). She defines dramatic activities as "the direct result of the ability to role-play - to want to know how it feels to be in someone else's shoes"(ibid.). Role-play apparently constitutes a sub-category of drama activities.

What was not meant by drama activities is:

- putting on a play for a passive audience

- a stiff ‘dramatization' of dialogues and sketches

- a mechanical memorization of dialogues or sketches

- part of a preparation for a great final performance (Pitman 1997: 6)

- teaching drama or about drama (Bolton 1986: 18)

Drama activities therefore avoid mechanical language reproduction and foster creativity and meaningful learning. The list further indicates the tension about the term drama which had led to a process/product; theater/drama divide, which is a more subtle issue than was once thought and will be explained later in this article.

In general, and closely related to Gardner's idea of multiple intelligences, ${ }^{7}$ Schewe defines drama in education as a way of teaching that "die wesentlichen Elemente bzw. Grundgedanken handlungsorientierter, erfahrungsbezogener, interaktiver und alternativer Sprachlehransätze zusammenführt." ${ }^{8}$ Common to all definitions of drama in education is the attempt to promote a more holistic way of learning and the effort to connect life outside the classroom with formal ways of teaching in the classroom.

\section{The Paradigms}

Although this project is not based on a large-scale study, but on a one-time experience, I believe that the outcomes highlight certain tendencies in students' learning experiences and might be transferable to similar situations. One student had performance experience prior to this class because she was a theater major. The course was an advanced composition and conversation class, mandatory for all German majors, and took place during one fifteen-week semester. The class met twice a week for seventy-five minutes. As one part of the

\footnotetext{
${ }^{7}$ Gardner developed the theory of multiple intelligences or learners' proclivities and suggested that testing and teaching methods ought to include ways that reach students other than in a logical-mathematical manner. See Gardner, Multiple Intelligences. The Theory in Practice: A Reader, New York: Basic Books, 1993. 8-9. In relation to Gardner see also Armstrong, Multiple intelligences, Nov. 8, $2006<$ http://www.thomasarmstrong.com/multiple_intelligences.htm>.

8 "brings together the essential elements or basic ideas of language-teaching approaches that are hands-on, experiential, interactive, and alternative."(Schewe 1993:6 quoted in Even 2003: 53.)
} 
course, the students studied a shortened version of Alfred Andersch's Sansibar oder der letzte Grund based on Schewe / Wilms's adaptation of this novel in the form of drama lessons published in the Stundenblätter series by Klett. The Stundenblätter are to a compilation of commentated Unterrichtsbausteine or teaching modules, worksheets, background information, and excerpts of the reading material, in this case, sections of Sansibar. The class worked with the text for seven weeks. All the readings throughout the semester dealt with various forms of "otherness," i.e. ethnic and/or cultural differences. ${ }^{9}$ Lexical work and grammar exercises supported the accuracy of language use, both in speaking and writing. Short and longer essays, connected to the topics of discussion, helped students to improve their composition and writing skills, whereas discussions and drama activities encouraged them to practice forms of oral expression.

Instead of the more traditional final examination or research paper, the students were asked to create a play based on any of the readings. They had the choice of writing and performing a theater play or making a video. Interestingly, out of all the literary texts offered in their syllabus they chose Alfred Andersch's novel Sansibar. They opted for the film version and wrote an adaptation of the prose text as a film script. Both the students and I evaluated the work on this project and the resulting film. The participants also decided on the criteria for evaluation: regular participation in the meetings outside of class, contributions to the script and structural and lexical accuracy of the script, dramatic enactment, and adequacy of expression (see appendix).

\section{Why Sansibar?}

For this course, I had decided to make representations of the "Other"10 the overall topic because I wanted to address questions of cultural differences in Germany and include the students' own experiences of studying abroad as one way of preparing them for becoming future citizens in a globally interconnected world. Literature in L2 instruction confronts learners with new ideas and value systems, which they need to integrate into their personal cognitive and emotional experiences, and drama supports and facilitates these kinds of personality building processes (Tselikas 2002: 60-61). "Nothing gets learned

\footnotetext{
9 In Sansibar, "otherness" was represented by a young Jewish woman and by a member of the Communist party and both intended to escape from the Nazis to Sweden. The other texts that the students read were the first chapter of Claudia Rusch's Meine freie deutsche Jugend (2003), as a more recent literary expression than Sansibar about the dream of leaving an oppressing regime for freedom. Heinrich Böll's "Anekdote zur Senkung der Arbeitsmoral" (Turneaure, Der treffende Ausdruck: 1996), "Schick mir doch ein Mail" by Angela Kreuz (Teichert and Teichert, Allerlei zum Lesen: 2005), and two texts by Anant Kumar "Cayennepfeffer" and "Die drei Pistolen" (Kumar, Die uferlosen Geschichten: 2003) were the other texts for this class. These readings were supported by films such as Pepe Danquart's "Der Schwarzfahrer" and short scenes from "Keiner liebt mich" by Doris Dörrie.

10 Other is capitalized because I refer to it as a monolithic and fixed concept rather than diverse and fluid.
} 
until the new experience is integrated into the praxis of living," accordingly, drama functions as a stepping stone to true learning (Wagner 1998: 17). Hence, I opted for a literary text to start with because it offered many levels of interpretation and allowed the learners to study historical and cultural materials of the story's time period, in this case the Nazi era, and its effects on art, politics, and individual lives. The Schewe/Wilms Stundenblätter thus seemed to offer a tool not only to convey the material cognitively, but also to engage students emotionally for personal growth.

As questions of the Other and of Othering functioned as the main theme of the course, I felt that the processes and the anxieties that go along with various forms of Othering could be most appropriately experienced through this novel and with drama techniques. As Tselikas points out, drama intensifies the students' experience

indem Identitätsschichten erreicht und mobilisiert werden, die auch mit wichtigen Wertvorstellungen belegt sind. Das Paradoxe des Theaters, die Möglichkeit der Annäherung durch Distanzierung bildet hier eine wichtige Ressource, die es erlaubt, auch wert- und konfliktgeladene Thematiken anzugehen (2002: 62). ${ }^{11}$

Through both identification and distancing, the students learn about the anxieties of marginalized and persecuted social groups. In the story, a Jewish woman and a Communist are at risk and fear for their lives. These two characters represent ethnic and political groups, which had become extremely "Othered" or marginalized under Nazi ideology. Through initial dramatic enactments of various scenes, as suggested in the Stundenblätter, the students become sensitized to these problems and, as one of the overall goals for this class, ideally transfer this kind of experience to the other texts of the course and to experiences later in life.

\section{The Content of Sansibar oder der letzte Grund}

Before presenting the approaches and techniques in detail, a short overview of the content of the novel will be given in order to contextualize my teaching unit. Sansibar gives the impression of a documentary rather than a fictional work. Time and location are concrete and fixed: Rerik, October 1937. Historically, the Nazis had by that time tightened their control and largely deprived Jews of civil rights. Parties other than the NSDAP, such as the Communist party, were forced to work underground, and certain types of art designated as degenerate (Entartete Kunst) were confiscated. Andersch's novel is based on this historical background and all these tensions are played out in Rerik, which is a small town on the Baltic Sea. The location of Sansibar is a collage of landscapes filled with fictional characters, and none of the characters in the novel seem to care

\footnotetext{
11 ... by reaching and mobilizing levels of identity, that are infused with concepts of value. The paradox of theater, the possibility of drawing close by distancing creates an important resource, which permits one to tackle topics charged with values and conflicts. Trans. U.B.
} 
much for the others; the encroaching danger of the Nazis, however, forces them to cooperate. The central figure of Sansibar is a wooden statue, Der lesende Klosterschüler, (The Reading Monk) ${ }^{12}$ by Ernst Barlach. This sculpture stands in the church of Rerik and becomes a symbol of the thinking human being. The Nazis considered Barlach's art as Entartete Kunst and wanted to confiscate it. The successful rescue of the wooden figure, the escape of the Communist Gregor, and the flight of the Jewish woman Judith all depend on the willingness of the fisherman Knudsen to take them outside the country; he very reluctantly cooperates. In the novel, it is the sea route to Skillinge in Sweden offers the escape from oppression to freedom. ${ }^{13}$

Schewe/Wilms' Stundenblätter version is shortened and does not include the dreams of freedom of a teenage boy who struggles with the death of his father and feeds his imagination by reading Huckleberry Finn. He is the one who is looking for three reasons to leave his home:

1. In Rerik ist nichts los.

2. Rerik hat seinen Vater getötet.

\section{Es gibt "Sansibar" hinter der offenen See. ${ }^{14}$}

Sansibar is thus the last reason, der letzte Grund. Furthermore, the ending is shortened and motivations for specific actions by the characters are not as fully represented in Schewe's adaptation as in the original text. For example, Knudsen's refusal to go on this dangerous boat trip because he feels responsible for his mentally ill wife is not included as explicitly as in the original.

\section{What Works, What Requires Consideration?}

Schewe/Wilms' idea for a drama approach to Andersch's novel arose from a teacher training seminar taught at the University of Oldenburg in the 1990s, in which drama in education techniques for German as a foreign language were first tested in order to "pave a way to cultural learning" (Schewe quoted in Byram/Fleming 1998: 204). Schewe describes this project in his article Culture through Literature Through Drama (quoted in Byram/Fleming 1998: 204-221). Schewe/Wilms designed sixteen Unterrichtsbausteine or individual teaching sections between sixty and ninety minutes in length. Each Unterrichtsbaustein

\footnotetext{
${ }^{12}$ Der lesende Klosterschüler is translated as "The Reading Monk" in Schewe in Byram and Fleming, 1998: 214

${ }^{13}$ In reality, however, the statue was never carried to Sweden and Rerik is not really a harbor town; instead, it is a resort today (Schewe 1998: 221).

14 1. Nothing is going on in Rerik. 2. Rerik killed his father. 3. "Sansibar" is beyond the open sea. Beispielseiten von: Alfred Andersch, Sansibar oder der letzte Grund;Günter Krapp, Jürgen van de Laar, Die schülerorientierte Umsetzung von Anderschs Roman im Deutschunterricht der Sekundarstufe I und II, July 20, 2005, <http://www.zum.de/Faecher/D/BW/real/Sansi4.html\#Junge>.
} 
provides an Impuls or prompt, as well as the technique, and the explanations of the didactic functions, including the learning objectives. ${ }^{15}$ Schewe/Wilms guide the teacher and class through a number of preliminary activities. The students do not read the novel until Unterrichtsbaustein 10 in order to encourage students to speculate about the story, or in Schewe's words, to allow students to develop their inner films - shifting mental constructs as a result of learning processes. They are given excerpts from the text, instead, plus a map, pictures, data tables, and biographical information. All these materials serve as a bridge between the students' worlds and the world of the text (Schewe 1998: 220). ${ }^{16}$

In general, Schewe/Wilms's drama version of Sansibar can be recommended for both students and teachers new to drama-in-foreign language instruction because Schewe/Wilms have already converted the text into drama activities. The authors also provide background information on the novel, which saves much research time. In addition, all the activities are set up in logical steps that build up to a deeper and more complex understanding of the time and circumstances in which the characters of the novel operate. Schewe/Wilms also allow for other exercises providing themes for short essays and discussion topics. I will now concentrate on the Bausteine that worked well and those the students and I found problematic. I have broken down the teaching analysis into three parts: task, reaction, and comments.

\subsection{Unterrichtsbaustein 1 - Introduction}

The introductory lesson, "Unterrichtsbaustein 1," immediately confronts the class with a core sentence in the novel:

"Es wird bald keine Plätze mehr geben, an denen sich Menschen treffen können."17

Task: The students are asked to comment on this sentence without any information about the context from which it was taken.

Reaction: Most students related the meaning of the sentence to present-day situations such as the destruction of our environment, or the lack of public places for the sake of more roads, parking lots, and buildings. One student in the class made the connection with the persecution of Jews and other groups of people in the Third Reich.

Comment: Although this exercise is not about making this kind of historical connection or getting the right answer, the student's responses provided

\footnotetext{
15 Unfortunately the publication by Schewe/Wilms (1995) is out of print. However, for an online version (.pdf file) of the Unterrichtsbausteine developed by the authors click on the following link: http://www.ucc.ie/en/DepartmentsCentresandUnits/DepartmentofGerman/ StaffPages/Lecturers/ManfredSchewe/Research/Publications/DocumentFile, 26960, en.

${ }^{16}$ All the materials are available as copyrighted worksheets or Arbeitsblätter for the teacher to photocopy or to make transparencies. Schewe recommends buying the actual novel (Diogenes Taschenbuch, ISBN: 3257200552), if not for all students, at least for the teacher.

17 "Soon there won't be places anymore where people can meet." Trans. Schewe quoted in Byram/Fleming 1998: 205.
} 
the opportunity for a smooth transition to the novel. To me, this activity clearly demonstrated how text and the students' "inner films" intersect when students come up with various connections from a given prompt.

End of the Semester Review

Task: The same sentence was taken up in the last class of the semester, some time after the drama unit of Sansibar had been finished. This step was not suggested in Schewe/Wilms, but grew organically from this course.

Reaction: This time the students were able to expatiate about this sentence in more detail and with greater knowledge.

Comment: I suggest repeating this initial anchor at the end of the unit or the semester to form a learning circle, so that students can connect the beginning of the drama unit with its end and establish closure.

Unterrichtsbaustein 5 - Tracing the Lines

Task: It is not until Unterrichtsbaustein 5 that students are asked to explore forms of drama. Rather than confronting the students with a drama activity right away, the students are eased into this form of learning by working in small groups, tracing with their fingers on a photocopy the outlines of the face of the wooden figure Der lesende Klosterschüler, and then drawing this image on a separate piece of paper.

Reaction: The preliminary tracing of the outlines of the face did not seem to be very helpful for drawing the face afterwards. I could see in the students' faces some consternation while carrying out this activity.

Comment: The objective of this tactile and visual exercise, according to the didactic explanation in the Stundenblätter is "daß die Tn. [Teilnehmer, insert U.B.] sich ihre eigene sinnliche Vorstellung vom 'Lesenden Klosterschüler' machen" und "sich mit Anderschs (sprachlich ausgeformter) Betrachtung auseinandersetzten" (Schewe/Wilms 1995: 11).${ }^{18}$ Depending on the time available, I propose adding another preliminary activity, which helps students to move to a two-dimensional model via a three-dimensional one. The teacher could bring in a human mask or a doll with a face and the students could touch the lines and parts and then draw a picture based on the three-dimensional model. They could subsequently follow the task as given in the Stundenblätter and draw the face of the wooden figure presented in the xeroxed image (Arbeitsblatt 6) or one could leave out the step of Arbeitsblatt 6 . In this way, they are guided from a threedimensional, more realistic image, to a two-dimensional form. With the preliminary tactile exposure to the mask or the doll they could better understand the connection between the initial sensory experience and the more abstract task of creating a two-dimensional image of the monk's face.

Unterrichtsbaustein 8c - Character Diary

Task: In order to develop a stronger understanding of the main characters in the text - Knudsen, the fisherman; Judith, the young Jewish woman;

\footnotetext{
18 "the participants develop their own sensory image of the 'Reading Monk' and engage in
} Andersch's (aesthetically presented) thoughts" (trans. U.B.). 
Gregor, the Communist, and Helander, the priest - the students are asked to choose a favorite character and to keep a record of this figure throughout the text.

Reaction: Each student developed a preference for "his" or "her" character, especially whenever they were asked to play specific scenes of the novel. As an example: in the bar scene, the innkeeper asks Judith to show her passport because the police controls the guestbook in the evenings. Judith is afraid of being identified as a Jew and yet has to remain as calm and normal as possible in front of the innkeeper. She wins time by pretending a sudden interest for the harbor boats that she wishes to see outside. The student, who identified with Judith, really immersed herself in Judith's emotional world in this scene. Others in the class identified with their roles to varying degrees depending on their comfort level as actors.

Comment: Those participants who engaged in a somewhat restricted manner may have felt inhibited due to my presence, because I played the role of the audience, and thus remained the "critical" observer for them. The students acted their parts more convincingly in their final project, the video of the novel, which they produced entirely on their own. In addition, the written task provided the students with the opportunity to strengthen their active vocabulary and practice grammatical structures also based on feedback from me.

Unterrichtsbaustein 13 - Staring

Task: The students are asked to first stare into each others eyes, then to stare down someone of the group, and finally to simulate an interrogation.

Reaction: This activity is meant to make students understand the enormous psychological pressure the Jewish character experiences in her attempt to escape from the hands of the Nazi police. It can be very effective because of the strong emotional involvement, but it needs to be guided skillfully. In this case, I chose not to expose the class to such a "high-risk" activity (Dougill 1987: 27), such as staring at each other. At that point, I felt too inexperienced to handle this kind of task adequately.

Comment: For a dramatic rendition of a text of this complexity - culturally and historically removed from the students' lives and yet familiar to students of German in one way or other - it is advisable to establish and maintain a high comfort level for drama activities, at least for students new to the drama approach. Language instructors thus should use their own judgment of what they would like the students to explore or not. Their decisions should be based on what is acceptable for them as educators in relation to their students. As an alternative, I propose either to hold the moment of an interrogation as a tableau - the students can thus slip into different roles - or re-create the actual scene of Judith's encounter with the innkeeper as a tableau. In this way, the tension is contextualized in the novel, the students can take on a role, and further acting is not required. An analysis of the tableau can afterwards become the basis for a classroom discussion. 
These are some examples of how the Unterrichtsbausteine should be used flexibly and adapted to individual classroom situations. The Stundenblätter are set up like modules and include suggestions for alterations so that working with them did not strike me as a rigid regiment. One other important aspect, as addressed in the discussion of Unterrichtsbaustein 13 is especially the teacher's role in drama-in-education activities.

\section{Teacher in Role}

Whereas most critical texts on drama in education are concerned with the students' experiences in and through these activities, not much is said about the teachers in this setting. Admittedly, my anxiety level rose whenever the Stundenblätter instructions asked for a demonstration and placed me into the Teacher in Role situation, in other words, engaged me in modeling a situation. Dougill (1987: 33), for one, explains the value of modeling in its function of ensuring that students understand "the nature of the drama;" and second, in reassuring "the students that what is being requested of them is not unreasonable," and third, to make clear that the teacher in an authority position "is willing and able to engage in the activity". Gaudart (1990: 238) requires for language teachers in particular to know the "correct" gestures for a particular language/culture. Gaudart successfully used drama techniques in the 1990s as a ESL/EFL teacher in Malaysia and observed teacher trainees using drama in class. She acknowledges, however, that " $[\mathrm{T}]$ he idea that performance is required scares many teachers" and hence promotes a de-emphasis of "performance aspects" in teacher education in favor of a process-oriented approach (ibid. 247).

In order to lower teachers' anxiety level, Hamilton/McLeod (1993) bring the relationship between the teacher and drama in foreign language instruction into perspective. They point out that "drama is a way of thinking about teaching and learning." Not the idea of teaching languages should rule the teacher's mind, but the concept of being "a teacher of something through languages - a teacher of people, not a teacher of nouns, verbs, etc." (ibid. 14). ${ }^{19}$ Both authors further provide suggestions for language teachers new to drama, such as asking a drama colleague for help, organizing some form of team teaching, trying out drama activities in classes "with which I feel comfortable," and keeping a decent pace (ibid. 35). It seems to me that the Stundenblätter were meant for German teachers who had no or little experience with this specific approach. Some outside help would certainly have been desirable for me as suggested by Hamilton/McLeod, but did not materialize due to organizational constraints.

\footnotetext{
${ }^{19}$ As I will point out later, this kind of holistic perspective can be misunderstood by students who are used to more traditional, grammar-oriented, forms of instruction.
} 


\section{Mid-Semester Survey}

While teaching Sansibar oder der letzte Grund, I had the overall impression that the students were enjoying the activities. They seemed motivated, it took very little effort for me to engage them in the various drama exercises, and the time seemed to fly by. During the middle of the semester, shortly before the end of this unit, the students filled in a questionnaire about their experiences with it. The survey asked them how they liked learning with drama techniques or if they would prefer the "traditional method," which I briefly described (see appendix). Generally, the students favored a combination of both approaches because drama activities were fun and one could move around, but they also would have liked to spend more time on textual analysis. One student said, "Die Dramapädagogik war interessant und hat Spaß gemacht, aber ich denke, dass ich durch eine traditionelle Methode mehr lernen würde" [Drama in education was interesting and was fun. I think, however, that I might learn more with the traditional method]. One student felt we had progressed too slowly and had spent too much time on a single text and pointed out that it should at least have been supported by additional texts. Other students acknowledged the fun factor in the drama activities, but felt they needed a more traditional approach to learn grammar and vocabulary. Only one participant fully supported the drama approach and expressed a stronger learning effect, writing, "Ich habe viel mehr von der Dramapädagogikmethode gelernt. Es ist kreativer und lustiger" [I learned much more through the drama in education method. It is more creative and fun]. Another student mentioned the value of the group project, i.e. the video.

For some students, fun and learning seem to be mutually exclusive, probably because they had been trained to associate learning with effort and fun with relaxation and a lack of new learning. As one of the students pointed out, "Manchmal kann die Dramapädagogik sehr (zu) lustig sein" [Drama in education can sometimes be very (too much) fun]. ${ }^{20}$ Gaudart found in her survey in Malaysia, that begun in 1978 with over 300 secondary and tertiary teachers, that learners with intrinsic motivation fully accepted the drama approach, but among those with extrinsic motivation "there were some who felt they were having too much fun [...] to be learning much" (1990: 234). What these students may not have realized is that their learning takes place in many different forms and the learning effects through drama techniques are not likely to be testable in a traditional form of assessment. The results might reveal themselves in situations outside the classroom, even years later after they have left school.

\footnotetext{
20 The students gave me permission to quote their evaluations and I edited their quotes in terms of grammar and spelling.
} 


\section{Reflection}

This first experience with drama in foreign language instruction was very enriching for me. Very rarely had any of my previous classes developed such a strong cohesion and willingness to cooperate. After the drama unit, initially shy students participated enthusiastically in all other class activities. Even skeptical students did not refuse participation but seemed curious enough to want to try out new ways of learning. Nevertheless, this first experience with drama in education was not perfect for me. A second time around, I would, as Heathcote suggests, concentrate on creating significance more prominently (quoted in Johnson/O'Neill 1984: 25). Significance can be achieved by creating "moments of tension," which in turn offer a "new focus and create new awareness" and thus make learning meaningful (cf. Johnson/O'Neill 1984: 25). Although students should feel comfortable in their roles, some tension for excitement can augment stimulation and the learning process. With more experience I will urge the students to fully explore the tensions that Schewe/Wilms create in various drama activities in Sansibar, in order to make learning language and culture richer.

In retrospect, I am convinced that fictional works and their dramatization bring "a degree of authenticity" (Heathcote/Bolton 1994: 160) and crosscultural empathy to language learning which a more traditional, analytical approach may not achieve. Considering that my students were primarily used to more traditional techniques and thus had specific attitudes toward formal teaching, a combination of drama in education and a more analytical approach seemed most suitable to the learners' needs. I would therefore opt for a compromise between a drama-oriented approach and more traditional procedures of language learning, especially in senior level classes where most of the students' learning has already taken place in a logical-analytical manner. In this way, the students are encouraged to explore new input in unconventional ways and at the same time are presented with familiar approaches to learning.

While my class chose not to stage a play and opted for creating a film instead, the results were of equally high quality as those of a theater performance. This positive filming experience certainly supports Moody's conviction that a product-oriented approach definitely has its value and place in foreign language education (2002: 154). Experts on educational drama distinguish between process-oriented drama or informal drama for the purpose of acting such as role play, and product-oriented drama or drama for the purpose of performance, such as a theater play (Dougill 1987: 2 and Moody quoted in Byram/Fleming 2002: 135-136, Kao/O'Neill 1998: ix). The discussion about whether drama should serve a psychological function rather than an aesthetic one is carried out over the question of a process- vs. a product-oriented approach. Hornbrook aptly describes this debate from a Marxist perspective in Education and Dramatic Art and argues for a combination of both because a performance often constitutes a highlight in a student's life and remains memorable for a long time $\left(1998,2^{\text {nd }}\right.$ ed.: 139) in addition to providing multiple important learning effects. Moody 
(2002) also rejects a purely process-oriented approach to drama. He, like Hornbrook, promotes a combination of process- and product-oriented drama and argues that a process-oriented approach is only effective if "small-scale products" are planned as well so that students see their efforts appreciated (quoted in Bräuer 2002: 136). I doubt whether this class would have developed a strong team spirit or would have used their creativity so extensively had there not been the film as a final project. I wonder if they would have deepened their knowledge about the aesthetic language of the text or of the foreign language to the same degree had they been taught the materials under more traditional circumstances.

As the culmination of the semester, the video brought everything together which the class had practiced prior to the filming sessions. The video could thus be considered a natural extension of the Stundenblätter activities. When the students turned text into film, the characters of the novel really took shape. They combined words with gestures, they stressed intonation, and strove for accuracy in diction and grammar. Even more, they added a touch of humor to the seriousness of the novel by using a garden gnome for Barlach's wooden figure and by including one of the students' pet rabbits. They spent many extra afternoons and weekends on writing and editing the script. They took great care in choosing the appropriate locations for shooting the scenes, and they brought out the overall anxiety and tension of the characters through their choice of camera angles and close-ups. During the viewing session at the end of the semester, everyone received a copy of the film on DVD so that this special experience was made permanent for each participant and could be shared with others in the future. This class project clearly demonstrated how a combination of a process- and product-oriented approach to drama can work effectively.

\section{Conclusion}

I believe that drama in foreign language education needs to be recognized and implemented as a valid approach for teaching literature for students in the $21^{\text {st }}$ century. Drama in education facilitates learners' access to foreign languages. They develop a deeper level of cross-cultural understanding, which might inspire them to view the study of foreign languages and cultures as a life-long endeavor. Drama in education thus offers a method with a high potential for effectively achieving foreign language goals.

Acknowledgments - Many thanks go to the anonymous reviewers; further to Susanne Even, David Dollenmayer, Colleen Martin-Moceri, Manfred Schewe, and Gerhard Strasser for their valuable contributions to this article. 


\section{Bibliography}

Alexander, Robin (2005): Culture Dialogue and Learning: Notes on an Emerging Pedagogy. 2-3, 16-18. November 30, 2006 <http://www.robinalexander.org.uk/docs/IACEP_paper_050612.pdf>

Armstong, Thomas (1998-2000): Multiple Intelligences. July 20, 2005 $<$ http://www.thomasarmstrong.com/multiple_intelligences.htm>

Bolton, Gavin (1986): Selected Writings on Drama in Education. New York: Longman

Bolton, Gavin (1984): Drama as Education. An Argument for Placing Drama at the Centre Of the Curriculum. Harlow: Longman

Bowker. Publishing Central. October 17, $2006<$ http: //www.publishingcentral.com/articles/20060516-23-2748.html>

Bräuer, Gerd (ed.): Body and Language: Intercultural Learning Through Drama. Advances in Foreign and Second Language Pedagogy. Vol. 3. Westport, CT: Ablex Publishing

Brown, Joanne (2000): Teaching Drama: Text and Performance. Paper presented at the Annual Meeting of the National Council of Teachers of English. Milwaukee, WI. November. 16-21

Byram, Michael / Fleming, Michael (eds) (1998): Language Learning in Intercultural Perspective. Approaches Through Drama and Ethnography. Cambridge: Cambridge University Press

Dougill, John (1987): Activities for Language Learning. London: Macmillan. Educational Cyber Playground. October 17, 2006 <http://www.edu-cyberpg.com/Literacy/what.asp>

Even, Susanne (2003): Drama Grammatik. Dramapädagogische Ansätze für den Grammatikunterricht Deutsch als Fremdsprache. München: iudicium

Hornbrook, David $(1989,1998)$ : Education and Dramatic Art. New York: Routledge

Gardner, Howard (1993): Multiple Intelligences: The Theory in Practice. New York: Basic Books

Gaudart, Hyacinth (1990): Using Drama Techniques in Language Teaching. In: Sarinee, Anivan (ed.): Language Teaching Methodology for the Nineties. Anthology Series 24. Singapore: Southeast Asian Ministers of Education Organization. Regional Language Centre, 230-249

Hamilton, Judith / McLeod, Ann (1993): Drama in the Languages Classroom. London: Center for Information on Language Teaching and Research

Heathcote, Dorothy / Bolton, Gavin (1998): Teaching Culture Through Drama. In: Byram, Michael / Fleming, Michael (eds.): Language Learning in Intercultural Perspective. New York: Cambridge University Press, 158-177

Hornbrook, David (1998): Education and Dramatic Art. London, New York: Routledge ( $2^{\text {nd }}$ ed.) 
Johnson, Liz / O'Neill, Cecily (eds.) (1984): Dorothy Heathcote. Collected Writings on Education and Drama. London: Hutchinson

Kao, Shin-Mei / O'Neill, Cecily (1998): Words into Worlds: Learning a Second Language Through Process Drama. Stamford, CT: Ablex Publishing Corporation

Krapp, Günter / van de Laar, Jürgen (2005): Die schülerorientierte Umsetzung von Alfred Anderschs Roman im Deutschunterricht der Sekundarstufe I und II. July 14, 2005 <http://www.zum.de/Eaecher/D/BW/real/Sansil.html>

Moody, Douglas J. (2002): Undergoing a Process and Achieving a Product: A Contradiction in Educational Drama? In: Bräuer, Gerd (ed.): Body and Language: Intercultural Learning Through Drama. Advances in Foreign and Second Language Pedagogy, Vol. 3. Westport, CT: Ablex Publishing, 135-159

McCaslin, Nellie (1996): Creative Drama in the Classroom and Beyond. New York: Longman

National Standards for Foreign Language Education. July 20, 2005

<http://www.actfl.org/i4a/pages/index.cfm?pageid=3392>

Pitman, Marge (1997): Cracking the Code: Literacy through Creative Drama. In: EDEL 570 Research Project. Long Beach: California State University, 1-27. October 3, 2006 $<$ http://eric.ed.gov/ERICDocs/data/ericdocs2/content_storage_01/0000000b/80/24/d7/49.pdf>

Schewe, Manfred / Scott, Trina (2003): Literatur verstehen und inszenieren: Foreign Language Literature Through Drama. A Research Project. In: German as a Foreign Language (GFL) 3: 58-63. October 7, 2006 $<$ http://www.gfl-journal.de/3-2003/schewe_scott.pdf>

Schewe, Manfred (2002): Literaturvermittlung auf dem Wege von gestern nach morgen - eine auslandsgermanistische Perspektive. In: German as a Foreign Language (GFL) 3: 25-47. October 7, 2006

<http://www.gfl-journal.de/3-2002/schewe.pdf>.

Schewe, Manfred (1998): Culture through Literature through Drama. In: Byram, Michael / Fleming, Michael (eds.): Language Learning in Intercultural Perspective. Approaches Through Drama and Ethnography. Cambridge: Cambridge University Press, 204-221

Schewe, Manfred / Wilms, Heinz (1995): Texte lesen und inszenieren. Alfred Andersch: Sansibar oder der letzte Grund. In: Krumm, Hans-Jürgen / Wilms, Heinz (eds.): Serie Stundenblätter Deutsch als Fremdsprache. München: Klett (a section of this publication is available online at



Tselikas, Elektra (2002): Dramapädagogischer Literaturunterricht als ein Prozess von interkulturellen Identifikationen und Grenzverschiebungen. In: Theorie und Praxis. Österreichische Beiträge zu Deutsch als Fremdsprache in Österreich. Wien: Studienverlag, 57-74 
U.S. Department of Education. International Comparisons in Fourth-Grade Reading Literacy: Findings from the Progress in International Reading Literacy Study (PIRLS) 2001. October 17, 2006

<http://nces.ed.gov/pubs2003/2003073.pdf>

Wagner, Betty Jane (1998): Educational Drama and Language Arts. What Research Shows. Chicago: Heinemann 


\section{A Appendix A}

\section{A.1 Bewertung der Unterrichtseinheit Sansibar oder der letzte Grund}

Nach traditionellem Muster hätten wir einen Text zunächst gelesen, dann Fragen dazu beantwortet und evtl. einen Aufsatz dazu geschrieben. Stattdessen habt ihr nach der sogenannten Dramapädagogik Methode kleine Szenen gespielt, gezeichnet, ein Videoskript entworfen, die Charaktere in Form und Farbe symbolisiert, Masken verwendet und Kurzaufsätze geschrieben.

1. Nach welcher Form hättest du lieber den Text erarbeitet?

1. traditionell

2. nach der Dramapädagogik?

1. Bitte erläutere kurz deine Wahl:

2. Glaubst du, dass du mehr oder dass du weniger nach dieser Methode gelernt hast? Warum?

3. Was gefiel dir besonders gut an dieser Art der Texterarbeitung? (Falls noch nicht in 1 beantwortet).

4. Wenn du den Unterricht gemacht hättest, was hättest du anders gemacht?

5. Was möchtest du deiner Professorin noch mitteilen?

Herzlichen Dank!! 


\section{B Appendix B}

Table 1: Bewertungskriterien für das Videoprojekt

\begin{tabular}{|l|l|l|l|}
\hline Teilnahme: & & War immer bei den Treffen dabei & $10 \mathrm{P}$ \\
\hline & & Hat Mal gefehlt. & $-1 \mathrm{P}$ pro Fehlen \\
\hline Einsatz: & & a. Hat Initiative gezeigt & $1-10 \mathrm{P}$ \\
\hline & & b. Hat extra Arbeiten übernommen & $1-10 \mathrm{P}$ \\
\hline & & c. War verlässlich & $1-10 \mathrm{P}$ \\
\hline Ausführung & & Aussprache & \\
\hline & Sprache: & Grammatik & $1-10 \mathrm{P}$ \\
\hline & & & $1-10 \mathrm{P}$ \\
\hline & & Kameraführung & $1-10 \mathrm{P}$ \\
\hline & Filmtechnik: & & \\
\hline & & Props, Szenen, Kostüme & $1-10 \mathrm{P}$ \\
\hline & Gestaltung: & $1-10 \mathrm{P}$ \\
\hline & & & $1-10 \mathrm{P}$ \\
\hline & & im Text &
\end{tabular}

